Candidate of Pedagogical Sciences, Associate Professor, Associate Professor at the Department of Higher Mathematics of Ivan Kozhedub Kharkiv National University of the Air Force

O. M. Zelenska

Candidate of Pedagogical Sciences, Associate Professor, Associate Professor at the Department of Aviation English of Ivan Kozhedub Kharkiv National University of the Air Force

\title{
THE PROBLEM OF FORMATION OF EDUCATIONAL ENVIRONMENT IN G. S. SKOVORODA'S PHILOSOPHICAL AND PEDAGOGICAL HERITAGE
}

In the article G.S Skovoroda's life and the formation of his scientific world outlook, conceptual origins of his progressive teaching that is focused on ethical and humanistic issues of mankind have been analysed. Based on the study of G.S. Skovorada's philosophical and pedagogical heritage, the essence of the notion of educational environment in its macro- (the nature), symbolic (the Holy Scriptures), micro measurements (the man) have been dealt with. The philosopher's framework of categories concerning his definitions of the notion of the environment (macrocosm, microcosm, world (мыр), little world (мырок), substance) have been determined. Such principles of its formation as natural conformity, succession, affinity have been defined. The publication also shows Skovoroda's role in the formation of education of our country, the fundamental importance of his progressive teaching in philosophical and pedagogical interpretation of the interrelation of the man and the environment, natural upbringing, self-knowledge, self-actualisation, self-improvement, and selfdevelopment of a "true person's" personality; it proves that Skovoroda's humanistic ideas make conceptual ground for the formation of educational environment at a global, national, local and individual level; analyses the ideas of modern scholars regarding the essence, structure and structural elements of the educational environment at educational institutions, its influence upon a personality in the context of G. S. Skovoroda's philosophical and pedagogical heritage.

The publication reveals the philosopher's main pedagogical principle which lies in the idea of "natural education" involving the interrelation of the laws of nature and society's life, properly appraising the role of the social surrounding in the area of education. It also deals with Skovoroda's views about the importance of self-cognition for the purpose of one's "affinity" which can be traced in the humanistic concepts of human-, child- and cordo-centrism as well as the educational paradigm about orientation at the formation of every pupil's personality, his creative life, professional self-determination and self-realisation. The significance of the right education in the society along with the possibility of inheriting natural genes in one's aptitudes are emphasised.

Key words: educational environment, macrocosm, microcosm, symbolic world, poem, substance, natural upbringing, self-knowledge, affined work.

Problem statement. The modern situation in the national educational system is characterised by the two processes that are mutually exclusive at first glance. On the one hand, the integration of the Ukrainian national system into the European and world educational systems is still in process. On the other hand, the issues concerning the possibilities of making an individual educational trajectory for each pupil or student and following it during study as a result of exceptional individual personality aptitudes, inclinations and needs are becoming of significant importance. Therefore the reformation and improvement of the Ukrainian educational system are accompanied by both global international processes and providing the conditions for personality's selfrealisation, its self-development, formation of spiritual culture, humanistic values and priorities.
The analysis of recent publications. It is generally acknowledged that the important factors of personality's development are the environment and the society. The scholars N. Gontarovska, V. Lozova, A. Trotsko, A. Mudryk, V. Yagupov traditionally single out macro factors (country, society, state, culture), meso factors (ethnos, region, type of settlement, means of mass communication), micro factors (family, micro community, educational institutions, religious organisations) among the above mentioned factors. The research of G. Skovorodas's philosophical and pedagogical heritage shows that the conceptual sources of these ideas can be found in the works of the Ukrainian philosopher-traveller, fable writer and pedagogue, in his theory about the macro world and micro world, affined work, a veritable man whose properties, "that raise him over the animal 
world, are intellect, sense, language, education, scholarship".

The aim of the publication is to study the phenomenon of the educational environment as it was understood and realised by G. Skovoroda in his pedagogical work.

Material report. The surrounding medium provides a man with a physical basis for life and enables his intellectual, moral, social and spiritual development. A man is at the same time both a product and a creator of his medium, that is why the two aspects - natural environment and artificial environment, made by a man - are essential for people's welfare and realisation of the main human rights, including the right to live.

In the philosophical and pedagogical interpretation of the interrelation of the man and the medium significant attention should be focused on the anthropological views of the Ukrainian philosopher Grigory Skovoroda. According to Skovoroda, the essence of the notion "medium" interacts with the properties of such notions as "world", "macrocosm" ("macrocozm"), "microcosm" ("microcozm"), "substance", "world" ("мыр"), "little world"("мырок").

Let's track the evolution of Skovoroda's scientific view of the world and his life journey. The future philosopher-traveller was born on November, 22 in 1722 in Poltava region into the family of a land-poor Cossack. He must have absorbed freethinking and such trends as existentialism out of his father's Cossack education.

GrigorySavich Skovorodagothis primaryeducation at a country school, in 1738 he entered Kiev-Mohyla Academy where he studied until 1741 and where he acquired good command of languages, philosophy of antiquity, Middle ages and Renaissance. After graduation from the Academy in 1742, Skovoroda was a singer in a tsarist choir in Petersburg for three years, however the court career was not appealing for him. In 1744 he continues his studies at the Academy, and upon graduation in 1750 he was sent to Hungary as a member of the Polish mission travelling around Austria and Germany.

G. Skovoroda's pedagogical work started since 1753 , he worked as a teacher of pyitics at Pereyaslav seminary where he introduced a lot of innovative ideas, neglecting the established teaching methods, displeasing the seminary's governing body. After his dismissal, Skovoroda applies as a home teacher of the landowner Stepan Tomara in his family estate Kavrai in Pereyaslav region. The situation was favourable for the philosopher's walks around the village's outskirts, getting to know the life of common people, cognizing both himself and the surrounding world.

Skovoroda spentmore than half of his life in Sloboda region. From 1759 to 1769 he worked at the College, Kharkiv where he taught pyitics, syntax, catechesis.
Over the last years of his life the philosopher travelled around Sloboda region, visiting the manorial estates of the Karazins, Kvitka-Osnov'yanenkos, DonetskZaharzhevskys, Mechnikovs, Tev'yashovs, as well as the monastery estates of Kuryazh, Ohktyrka, Sumy oblast, Svyatogorsk. They were the philosopher's fruitful years: he writes philosophical dialogues, poems, treatises, fables (in the Old Ukrainian, Old Church Slavonic languages and Latin). Orally or in writing, Skovoroda propagated the knowledge about the man and the world among common people, that is why Grigory Savich was figuratively referred to as "a travelling university". However, Skovoroda was one among those who inspired Vasily Karazin to found Kharkiv imperial university: the money to open the university had been raised by the friends and supporters of Skovoroda's creative work. They commented on his personality: "We got our own Pythagor, Origen, Leibniz under a Cossack's forelock and in a Ukrainian peasant's overcoat". The philosopher died October, 29, 1794 in the village of Ivanivka (Skovorodynivka) in Kharkiv oblast.

As a student, he had long since demonstrated his freethinking, independence in views and critical perception of what he was studying. For example, while Kyiv-Mohyla professors focused their attention on the outer world and gnoseology, the student Skovoroda studied the man and ethic and humanistic problems of mankind. Although the professors of Kyiv-Mohyla Academy were dominated by the ideas of Aristotle's scholastic philosophy, Skovoroda's philosophical views were formed under the influence of Plato's idealistic theory. As it is known, Aristotle and his followers characterised the surrounding medium by the active property to influence the interrelation between objects forming a sensitive substance. By Plato's objective-idealistic views, a medium - is a special world of endless ideas surrounding the man, besides, every idea makes absolutised sense of all things. The reflection of this world of ideas, its reproduction and realisation is the cosmos including the nature and the society. Plato distinguished the two worlds: the world of clear ideas ("OH"), the real and true world, and the world of separate things "Me $\mathrm{OH}^{\prime}$, i. e. the untrue and flaunty world, as the things exist only because and as long as they reflect the ideas correlated to them in themselves. The ideal world comes to be filled with the things, people, natural and social phenomena, not only given in the form of clearly formulated and immovable prototypes but also the ones that are constantly transformed into the material reality under the influence of the present idea. The world, as it is perceived by the man, is a distorted shadow that casts the flame of the truth onto the wall of the cave where the mankind is $[1$, p. 56]. As the study of Skovoroda's philosophical works "The dialogue about the ancient world", 
"Friendly talk about the spiritual world", "Alphabet of the world" show, these very ideas of Plato's school were used by Skovoroda as the basis of his teaching about the three worlds, two natures etc. The roots of Skovoroda's philosophical and pedagogical views are also found in the biblical texts, philosophical works of the ancients Epicurus, cynics, Plutarch, Stoics, in the books of the enlighteners: Socium, Lokk, Kalvin, Melachton, Martin Luther, Campanella, Giordano Bruno.

While solving the problem of opposing the substance and the subject, the nature and spirit, the need and freedom, Skovoroda stuck to the idea that the surrounding reality is made by the three interrelated worlds: macrocosm, microcosm and the world of symbols. According to Skovoroda's philosophical views, macrocosm is the nature, microcosm is the man, the world of symbols connects the first two worlds and its fullest manifestation is the Bible. Microcosm contains the big world or the world of nature, "general and the world of abode". Microcosm (microcozm) - the man reflecting macrocosm is a symbol, the centre of power and intellect of the world and creation; the inner world of the man contains the whole Universe, universum. Religion is an integral combination of the man and nature where a religious personality feels to be an element of a cosmic organism, God's particle: "We are in Him, and He lives in us. And Moses' symbolic world is a book that leads to the single omnipresent origin as a magnetic arrow" [2, p. 18-19]. The conceptual origins of this view that God revealed himself in the nature (macro world), the man (nature), the Holy Scriptures (Bible's symbols) come from the ones of the classical thinkers Philo and Clement of Alexandria.

According to Skovoroda, in every person, as in everything that exists, there is the visible and invisible, the corruptible and eternal. A true man in a man is the invisible nature, the inner man opposed to the outer world and lost in it.

The key category in Skovoroda's philosophy was the notion of the "affined work". The travelling philosopher brought forward the idea that man is happy just in searching for and finding the work which is affined to its own nature and corresponds to the man's natural aptitudes: "Do you want to be happy? - be contented in your own lot". Without being able to do affined work "the neighbours seem to be disgusting, amusements appear to be boring, relatives - unpleasant, the night - tiresome, and the day - annoying". Only the affined work that cheers up the spirit, gives pleasure and enjoyment from the process of creative activity, is equally beneficial for the carriers of macrocosm and microcosm, as it helps people to cognize themselves, getting the knowledge of the laws of nature: Eucharist doesn't unite the man with God, but cognizing oneself does".
An integral component of G. Skovoroda's manysided activity was the philosopher's pedagogical work. The issues of education were studied by him in such his works as: the treatise "The initial doors to good Christian life" (course of ethics), the collection "Kharkov fables", the parables "Thankful Eurody", "Wretched Lark" and his correspondence. In his handwritten collections "Garden of divine songs" and "The fables of Kharkov" Skovoroda urged people to obtain knowledge. Skovoroda's didactic principles were concentrated in his songs and aphorisms that are still perceived emotionally by readers projecting this or that parable situation onto personal experience, taking to heart the philosopher's appeal to be aware of one's destination and follow it all one's life since every person tries to choose the trade corresponding to his/her ideas about himself/herself, and G. Skovoroda deeply believed in a man's intellectual capabilities and his significant intellectual potential. Modern scholars actively study psychological and pedagogical phenomena of personality's self-knowledge, self-education, self-actualisation, self-improvement and selfdevelopment that are possible, provided the chosen trade corresponds to man's "Self-concept" as a steady system of personality's ideas about him/ herself. When comparing "the trade image" with the image of his/her "Self", a student becomes aware of his identity with the chosen trade, affinity to it [3].

The main pedagogical principle, according to Skovoroda, was the idea of "natural education" that had been enunciated by him before Rousseau and Pestalozzi. However, the Ukrainian thinker managed to avoid narrow-mindedness in determining the role of nature in man's life. For example, Skovoroda's contemporary, the French philosopher pleaded: 'Almighty God, holding peoples' minds in your hands, deliver us from education and pernicious knowledge of our forefathers and give us back our illiteracy and wretchedness as the only welfare that can make us blessed" [4, c. 62]. While our countryman recognized the interrelation of the laws of nature and society's life, properly appraising the role of the social surrounding in the area of education. Calling upon for unity with the nature, Skovoroda admitted the role of education, creative personality's ethical and esthetical development on the works of classical literature, philosophy and other factors of human civilization. He did not deny the possibility of inheriting natural genes in one's aptitudes, but he also greatly emphasised the right education in the society.

Skovoroda extolled "harmonia praestabilita" (foreseen harmony, general connection and consistency of simple substances in the world, G. Leibnitz) between the sociality and the man, based on the affined work and activity in reconciliation and unity with the nature. By Skovoroda, for his 
existence a man needs such environment that influences an individual since birth and is of universal character. The man in this environment is presented as a being that is self-developed and self-realised as a subject, a result of one's own activity. This global environment is the nature: "Every affair is successful when it is furthered by the nature. Just don't interfere with it and when you can, remove the barriers as if clearing the way for it". Such advice was given by Skovoroda to parents and teachers whom he considered to be nature's helpers and votaries in the field of education. As good education begins in a family and the first and the best child's teachers are his/her parents who should take into account the astrological rules of a good birth in child's bearing: "If someone wants to learn to do something, he should be born for this". In addition to a good birth, the basis of family education is made up by the care for child's health and cultivating gratitude ("Grateful Eurody").

Then professional teachers and school come to help them. And the very first teacher's task is to identify the affinity of a young man, to see what aptitudes he has, watching his "soul's every shadow" and "nature's sparkles". In addition to parents' and teachers' education, a person should educate him/herself on his/her own.

Skovoroda did not express his productive and democratic ideas only in his works, he also realised them practically being a college teacher or a home teacher. Although pedagogical work was appealing for Skovoroda, he lacked the audience with which he could share his thoughts and which he could influence. During his work at the college he ran active pedagogical activity among the youth. He led discussions with his favourite students explaining the essence of things in the surrounding world to them. According to Skovoroda, a man can know the world though himself by staying in solitude and looking into himself. That is why, in our opinion, Skovoroda felt cramped within the college's walls, all the nature made the educational environment for him and, at the same time, so did seclusion, being able to avoid temptations. According to Skovoroda, getting to know the essence of the biblical symbols is not the job meant to be done in a study. On the contrary, every person under particular life circumstances and needs to decipher some or other symbols of the Bible, can and should study the Holy Book every day. Only by looking into oneself one can know God's nature, besides it is essential to clear one's consciousness from violence since human will gives rise to offence and lawlessness. One should be in the mood for God's will which was identified by Skovoroda with law, movement and time. However, by Skovoroda, the man is not only a passive part of the material world, as a human soul is connected with God as the Creator of all, and therefore it is endowed with a part of heavenly power, the ability to carry out independent actions. To create, a man must study his/her creative abilities. Besides, selfknowledge is also beneficial because while getting to know himself, a man also gets to know his God, own Creator, his supreme will on w everything in the world depends $[5 ; 6]$.

Thus, the way of happiness, by Skovoroda, is selfknowledge, cognition of one's "blissful mother-nature", getting away from the world of evil and achieving freedom and the area of spirit. Generally, cognitive capabilities of human intellect are limitless since general laws of nature are embodied in human existence, it is enough to know oneself in order to learn the laws of micro world and micro world.

One should mention that Skovoroda's ideas about the all-merciful nature endowing the man with affined inclinations are developed in the works of KvitkaOsnov'yanenko, Illya Mechnikov and other scholars.

It is also worth mentioning that together with Skovoroda the progressive-minded pedagogues of Kahrkiv college widened their students' horizons. Following J. Komensky's pedagogical ideas, the study in the college required intentional comprehension of the syllabus material and its realization with life. Nevertheless, a number of teachers treated Skovoroda with animosity and tried to guard the young people from his influence by all means. The delivered course "Christian virtue" became unfavourable at the college whose pedagogical process was mainly based on scholastic ideas. As he was forced not to meet his students-followers, Skovoroda carried on correspondence with them. For example, in Skovoroda's letters to his pupil Mihailo Kovalinsky the pedagogue outlines the main directions of good professional education: holding to Christian virtues, rejection of the world's futility, seeking seclusion, Christ's poverty and chastity, fighting weaknesses, a chaste life, "golden measurement", being moderate in everything, soterial conversations with oneself, patience, knowledge of the holy languages, reading the Bible and ancient Pagan philosophers and Fathers of the Church. G. Skovoroda insisted: "You should study long yourself if you want to teach others. The fruit of all the sciences and arts is practice". Learning "doesn't live in knowing but in doing", creative experience is the father of art, knowledge and books. The philosopher was convinced that nobody is born an artist, only constant practice in the affined work can lead a man to a happy destiny. Work is connected by Skovoroda with the activity that does not contradict a man's natural aptitudes [7].

Conclusions. The study of Skovoroda's philosophical and pedagogical heritage proves the scholar's academic interest in the issues of the interaction between the man and the environment. The man was considered by Skovoroda to be microcosm where the laws of macrocosm are reflected, that is why it is possible to learn them by cognizing yourself every day and studying the Bible where 
symbols are codified. According to Skovoroda, a man's educational environment is the microcosm reflected in the macrocosm.

Skovoroda's principles about the importance of self-cognition for the purpose of one's "affinity" can be traced in the humanistic concepts of human-, childand cordo-centrism, the educational paradigm about orientation at the formation of every pupil's personality, his creative life, professional self-determination and selfrealisation. In our opinion, Skovoroda's postulate about happiness, voiced by the chancellor of G.S. Skovoroda Kharkiv National Pedagogical University, academician I.F. Prokopenko, is still of great topicality: "He whose inner interest agrees with the general interest, is happy". Being guided by Skovoroda's teaching, a pedagogue should find his position and help students to decide on the development program to search for one's place in life and keep contented about one's trade affined with its nature.

\section{References:}

1. Skovoroda G. S. Vibrani tvori. U 2 t. T. 2. Iz filosofskikh tvoriv. K. : Dnipro, 1971. 278 s.

2. Skovoroda G. S. Povne zibrannya tvoriv. U 2 t. T. 1 (Pisni. Bayki. Virshi. Traktati. Dialogi). K. : Naukova dumka, 1973. $531 \mathrm{~s}$.

3. Afanaseva L. Profesiyniy obraz "Ya» maybutnikh menedzheriv. Naukovi zapiski. Vip. 29. Seriya: Pedagogichni nauki. Kirovograd : RVV KDPU im. V. Vinnichenka, 2011. S. 44-49.

4. Russo Zh.-Zh. Izbrannye sochineniya. T. 1. M.: Goslitizdat, 1961.

5. Nizhenets A. Na zlami dvokh svitiv. Rozvidka pro G.S. Skovorodu i Kharkivskiy kolegium. Kh.: Prapor, 1970. $208 \mathrm{~s}$.

6. Ushkalov L. Grigoriy Skovoroda: seminariy. Kh.: Maydan, 2004. $876 \mathrm{~s}$.

7. Polishchuk F.M. Grigoriy Skovoroda: seminariy. K.: Vishcha shkola, 1972.

Марченко О. Г., Зеленська О. М. Проблема формування освітнього середовища у філософській і педагогічній спадщині Г. С. Сковороди

Простежено життєвий шлях, вивчено наукову біографрію, становлення фрілософрського світогляду Г.С. Сковороди, ідейні витоки його прогресивного вчення, в фокусі якого знаходяться етико-гуманістичні проблеми екзистенції людства. На основі вивчення фрілософрсько-педагогічної спадщини Г.С. Сковороди розглянуто суть поняття освітнього середовища в його макровимірі (природа, всесвіт, Космос), символічному вимірі (святе писання, Біблія, книжковий світ), мікровимірі (людина, ії внутрішній світ, особистість). Визначено категорійний арсенал фрілософра-подорожника та поета щодо дефрініції ним поняття середовища (макрокосм, мікрокосм, світ, мыр, мырик, субстанція). На підставі вивчення поезій Г.С. Сковороди установлено визначальну роль середовища у формуванні особистості як ресурсу та сфери праці. Показана випереджальна роль Г.С. Сковороди у становленні освітньої системи, фундаментальне значення його передового вчення щодо фрілософьсько-педагогічного осмислення взаємного зв'язку людини та середовища, дотримання принципів природодоцільності, виховання особистості в дусі єднання з природою із збереженням індивідуальності, самопізнання, самоактуалізації, самовдосконалення, саморозвитку «істинної людини». Визначено такі принципи формування особистості в освітньому середовищі, як природодоцільність, наступність, педагогічний оптимізм, передбачена гармонія, споріднена прачя. Доведено, що гуманістичні ідеї Г. С. Сковороди $\epsilon$ концептуальним підгрунтям фрормування освітнього середовища на глобальному, національному, локальному, індивідуальному рівнях. Проаналізовані погляди сучасних науковців стосовно суті, складу, структурних компонентів навчально-виховного середовища освітніх закладів, його впливу на особистість у контексті фрілософосько-педагогічної спадщини Г. С. Сковороди.

Висвітлено основний педагогічний принцип філософа, який лежить в ідеї «природного виховання», що передбачає взаємозв'язок законів природи та життя суспільства, належним чином оцінюючи роль соціального оточення в галузі освіти. У статті також розглядаються принципи Сковороди про важливість самопізнання для своєї «спорідненості», що простежується в гуманістичних концепціях людського, дитячого та кордоцентризму, а також про освітянську парадигму щодо орієнтації на фрормування особистості кожного учня, його творчого життя, профресійного самовизначення та самореалізації. Розкрита роль освіти в суспільстві, а також значення успадкування природних генів для розвитку своїх здібностей.

Ключові слова: освітнє середовище, макрокосм, мікрокосм, символічний світ, поезія, субстанція, природодоцільність, самопізнання, споріднена праця, передбачена гармонія, істинна людина. 